\title{
ANALISIS TENTANG PENGGUNAAN JAMINAN FIDUSIA SEBAGAI DASAR PEMBERIAN PINJAMAN OLEH LEMBAGA PEMBIAYAAN
}

\author{
Muhammad Psake Pamungkas Sakti, Joko Priyono, Novira Maharani Sukma, \\ Program Studi Magister Kenotariatan \\ Fakultas Hukum, Universitas Diponegoro \\ Email : muhammadpsake@yahoo.com
}

\begin{abstract}
Financial institution is a business entitles that intended to do a financing activities such as providing funds or capital goods, and one of the business activities is Consumer Financing. In practices, the securities used is Fiduciary Security whereby the Fiduciary Grantor must be the owner of the fiduciary object. An agree and concur statement between fiduciary grantor and fiduciary assignor don't automatically transferred the ownership over fiduciary object before a transfer of rights occurs. The issue raised here is the application of Fiduciary Security as a basis lending by Financial Institutions. The writer use a normative method, and all the data analyzed qualitatively through the deductive method in order to reach the conclusions. This journal concludes: First: The object which has purchased by fiduciary assignor can be lended as Fiduciary Security to fiduciary grantor; Second : Regarding the movement or transfer of the fiduciary objects must still refer to the legal system warranty, which guarantees that fiduciary grantor doesn't become the owner of a fully justified on the fiduciary object; Third: Legality of Fiduciary Security for debt provided by the Financial Institution is based on the description of the fiduciary object.
\end{abstract}

Keywords : financial institution; consumer financing; fiduciary security

\begin{abstract}
Abstrak
Lembaga pembiayaan adalah badan usaha yang melakukan kegiatan pembiayaan dalam bentuk penyediaan dana atau barang modal, dan salah satu kegiatan usahanya yaitu Pembiayaan Konsumen. Dalam prakteknya, jaminan yang digunakan adalah jaminan fidusia dimana pemberi fidusia haruslah pemilik barang. Dalam hal pembiayaan konsumen dikaitkan dengan jual beli, adanya kata sepakat pembayaran belum mengakibatkan terjadinya peralihan hak milik sebelum dilakukan penyerahan. Oleh karena itu, permasalahan yang akan dibahas adalah penggunaan jaminan fidusia sebagai dasar pemberian pinjaman oleh lembaga pembiayaan. Penelitian ini menggunakan metode normatif yang hasil penelitiannya dianalisis dengan menggunakan metode analisis sumber hukum kualitatif. Penulis berkesimpulan: Pertama: barang yang dibeli oleh Pelanggan yang dibayarkan oleh lembaga pembiayaan dapat dijaminkan dengan fidusia kepada pemberi hutang/lembaga pembiayaan. Kedua: pihak yang dibiayai/pemberi jaminan/pembeli belum berkedudukan sebagai pemilik, dalam hal harga belum dibayarkan oleh lembaga pembiayaan. Ketiga: Legalitas Jaminan Fidusia untuk hutang yang diberikan Lembaga Pembiayaan didasarkan pada uraian objek jaminan fidusia.
\end{abstract}

Kata kunci: lembaga pembiayaan; pembiayaan konsumen; jaminan fidusia 


\section{A. Pendahuluan}

Istilah lembaga pembiayaan mungkin belum sepopuler dengan istilah lembaga perbankan. Eksistensi lembaga pembiayaan memang relatif masih baru jika dibandingkan dengan lembaga keuangan konvensional, yaitu bank. Lembaga pembiayaan ini kegiatan usahanya lebih menekankan pada fungsi pembiayaan, yaitu dalam bentuk penyediaan dana atau barang modal dengan tidak menarik dana secara langsung dari masyarakat. (Sunaryo, 2014)

Pasal 1 angka 1 Peraturan Presiden Republik Indonesia Nomor 9 Tahun 2009 tentang Lembaga Pembiayaan menyebutkan bahwa Lembaga Pembiayaan adalah badan usaha yang melakukan kegiatan pembiayaan dalam bentuk penyediaan dana atau barang modal. (Peraturan Presiden Republik Indonesia Nomor 9 Tahun 2009 Tentang Lembaga Pembiayaan, 2009). Dari ketentuan ini, Lembaga Pembiayaan merupakan suatu badan usaha, yaitu perusahaan yang khusus didirikan untuk melakukan kegiatan yang termasuk dalam bidang usaha Lembaga Pembiayaan. (Gozali, 2012). Berdasarkan Pasal 1 angka 2 Keputusan Presiden Republik Indonesia Nomor 61 Tahun 1988, Lembaga Pembiayaan adalah badan usaha yang melakukan kegiatan pembiayaan dalam bentuk penyediaan dana atau barang modal dengan tidak menarik dana secara langsung dari masyarakat. (Keputusan Presiden Republik Indonesia Nomor 61 Tahun 1988 Tentang Lembaga Pembiayaan, 1998).

Menurut Pasal 1 angka 1 Peraturan Otoritas Jasa Keuangan Nomor 29/POJK.05/2014 tentang Penyelenggaraan Usaha Perusahaan Pembiayaan, Perusahaan Pembiayaan adalah badan usaha yang melakukan kegiatan pembiayaan untuk pengadaan barang dan/atau jasa. (Peraturan Otoritas Jasa Keuangan Nomor 29/POJK.05/2014 tentang Penyelenggaraan Usaha Perusahaan Pembiayaan, 2014).

Ketentuan Pasal 1 angka 7 Peraturan Presiden Republik Indonesia Nomor 9 Tahun 2009 tentang Lembaga Pembiayaan yang dimaksud dengan Pembiayaan Konsumen (Consumers Finance) adalah kegiatan pembiayaan untuk pengadaan barang berdasarkan kebutuhan konsumen dengan pembayaran secara angsuran.

Lembaga Pembiayaan membiayai transaksi antara Customer (Pemohon untuk dibiayai dengan pihak ketiga) dikaitkan dengan Jual Beli dengan adanya sepakat dan pembayaran belum mengakibatkan terjadinya peralihan hak milik sebelum dilakukan penyerahan atau levering. Untuk memberikan jaminan bahwa seorang debitur akan memenuhi prestasinya maka digunakan Jaminan Fidusia. Dalam prakteknya lembaga pembiayaan konsumen ini sangat diminati oleh para konsumen didasarkan pada alasan-alasan bahwa proses/prosedur permohonan untuk mendapatkan pembiayaan sangat mudah serta tidak diper- 
lukan adanya jaminan barang-barang lain selain barang yang bersangkutan dijadikan obyek jaminan yang pengikatannya dilakukan secara Fidusia.

Seiring berjalannya waktu fidusia diakui berlakunya di indonesia sejak tanggal 18 agustus 1932 yang diputus oleh hoge Raad di belanda, putusan itu juga diikuti oleh indonesia dengan keputusan Hoogerechtchof $(H G H)$ yang terkenal dengan Batafshe Petrolium Maatshappij (BPM)-Cligne Arrest. (Andini, 2018).

Ciri-ciri jaminan fidusia diantaranya adalah memberikan hak kebendaan, memberikan hak didahulukan kepada kreditur, memungkinkan pemberi jaminan fidusia untuk tetap menguasai objek jaminan utang, memberikan kepastian hukum, dan mudah dieksekusi. (Aemadepa, 2012).

Berdasarkan Pasal 1 angka 1 Undang-Undang Nomor 42 Tahun 1999 tentang Jaminan Fidusia yang dimaksud dengan Fidusia adalah pengalihan hak kepemilikan barang tertentu dengan ketentuan bahwa barang yang hak kepemilikannya dialihkan tetap menjadi penguasaan pemilik barang. (Undang Undang Republik Indonesia Nomor 42 Tahun 1999 Tentang Jaminan Fidusia, 1999). Sedangkan berdasarkan Pasal 1 angka 2 yang dimaksud dengan Jaminan Fidusia adalah hak jaminan atas benda bergerak baik yang berwujud maupun yang tidak berwujud dan benda tidak bergerak khususnya bangunan yang tidak dapat dibebani hak tanggungan sebagaimana diatur dalam Undang-Undang Nomor 4 Tahun 1996 tentang Hak Tanggungan yang tetap berada dalam penguasaan Pemberi Fidusia, sebagai agunan bagi pelunasan utang tertentu, yang memberikan kedudukan yang diutamakan kepada Penerima Fidusia terhadap kreditor lainnya. Istilah jaminan merupakan terjemahan dari bahasa Belanda, yaitu zekerheid atau cautie mencakup secara umum cara-cara kreditur menjamin dipenuhinya tagihannya, disamping pertanggungan jawab umum debitur terhadap barang-barangnya. (HS, 2008).

Sumber yang melandasi lembaga jaminan fidusia ini adalah Pasal 1338 ayat (1) KUHPerdata, yang berbunyi "semua perjanjian yang dibuat secara sah berlaku sebagai undang-undang bagi mereka yang membuatnya". Pasal ini memberikan kebebasan pada para pihak untuk membuat perjanjian yang mereka buat, sepanjang tidak bertentangan dengan undang-undang, kesusilaan dan ketertiban umum.(Purwanto, 2012).

Dari uraian tentang UU Fidusia ini yang berarti Pemberi Fidusia itu haruslah pemilik barang. Ini berarti sudah terjadi penyerahan (Levering). Padahal harga belum dibayar, harga baru akan diterima oleh Penjual setelah Pelanggan mendapat pinjaman dari Lembaga Pembiayaan. Untuk mendapat pinjaman yang bersangkutan harus menyerahkan hak kepemilikan. 
Apakah mungkin Pelanggan menyerahkan hak kepemilikan padahal Pelanggan belum jadi Pemilik.

Dalam hal kepemilikan suatu benda dapat ditinjau melalui ketentuan mengenai jual beli. Pada Pasal 1457 KUHPerdata menyebutkan yang dimaksud dengan perjanjian jual beli adalah suatu persetujuan, dengan mana pihak yang satu mengikatkan dirinya untuk menyerahkan suatu kebendaan, dan pihak yang lain untuk membayar harga yang telah dijanjikan. (Subekti, 1980). Dalam ketentuan Pasal 1458 KUHPerdata menyebutkan bahwa jual beli itu dianggap telah terjadi antara kedua belah pihak, seketika setelahnya orang-orang ini mencapai sepakat tentang kebendaan tersebut dan harganya, meskipun kebendaan itu belum diserahkan, maupun harganya belum dibayar. Selanjutnya mengenai hak milik, Pasal 1459 KUHPerdata menyebutkan bahwa Hak milik atas barang yang dijual tidaklah berpindah kepada si pembeli, selama penyerahannya belum dilakukan.

Dalam hal lembaga pembiayaan dikaitkan dengan jual beli, dengan adanya kata sepakat pembayaran belum mengakibatkan terjadinya peralihan hak milik sebelum dilakukan penyerahan (Levering). Namun dalam perkara ini perjanjian yang terjadi menggunakan jaminan fidusia. Perjanjian Jaminan Fidusia tersebut sudah terjadi antara pelanggan dan lembaga pembiayan sebelum harga dibayarkan kepada penjual oleh Lembaga Pembiayaan dan sebelum ada penyerahan barang kepada pelanggan oleh penjual. Untuk itulah Penulis bermaksud menganalisis tentang Penggunaan Jaminan Fidusia sebagai Dasar Pemberian Pinjaman Oleh Lembaga Pembiayaan.

Berdasarkan uraian di atas, permasalahan yang akan dibahas dalam tulisan ini adalah pertama, apakah barang yang dibeli oleh pelanggan yang dibayar oleh lembaga pembiayaan dapat dijaminkan dengan fidusia kepada pemberi hutang/Lembaga Pembiayaan ? kedua, apakah pihak yang dibiayai/pemberi jaminan/pembeli harus sudah berkedudukan sebagai pemilik, padahal harga belum dibayar oleh lembaga pembiayaan ?

\section{- Kebaruan/Orisinalitas Hasil Penelitian}

Untuk memperkuat hasil penelitian, maka di perlukan kajian terhadap penelitian terdahulu yang di harapkan akan memaksimalkan penelitian yang penulis buat, kemudian di ikuti dengan penjabaran faktor pembeda antara fokus penelitian penulis dan fokus penelitian terdahulu yang menjadi rujukan penelitian ini. Berikut merupakan penelitian terdahulu yang dapat dijadikan rujukan oleh penulis: 
1. "Pendaftaran Jaminan Fidusia, Masalah Dan Dilema Pelaksanaannya", yang ditulis oleh Aermadepa. Jurnal ini membahas tentang pendaftaran jaminan fidusia, masalah dan dilema dalam pelaksanaannya. (Aemadepa, 2012).

2. "Kedudukan Fidusia Sebagai Jaminan Akad Pembiayaan Murabahah Pada Bank Syariah: Studi Kasus Pada BPRS Bhakti Sumekar Sumenep", yang ditulis oleh Isnani Yuli Andini. Jurnal ini membahas tentang kedudukan jaminan fidusia sebagai jaminan akad pembiayaan murabahah pada bank syariah. (Andini, 2018).

3. "Beberapa Permasalahan Perjanjian Pembiayaan Konsumen Dengan Jaminan Fidusia". Yang ditulis oleh Purwanto. Jurnal ini membahas tentang permasalahan dalam perjanjian pembiayaan konsumen dengan jaminan fidusia. (Purwanto, 2012).

Jika dilihat dari beberpa penelitian di atas, yang membedakan penelitian saya dengan penelitian di atas yaitu, penelitian saya lebih mengarah kepada barang atau objek yang dibeli oleh pelanggan yang dibayar oleh Lembaga pembiayaan untuk dijaminkan dengan fidusia kepada pemberi hutang/Lembaga pembiayaan dan hak milik dari objek yang dijaminkan dengan fidusia padahal harga belum dibayarkan kepada Lembaga pembiayaan.

\section{B. Metode Penelitian}

Desain Penelitian yang digunakan dalam penelitian iniadalah penelitian hokum normative disebut juga penelitian hokum doktrinal. Jenis penelitian ini beranjak dari telaah hokum positif yang kajiannya meliputi tiga lapisan dari ilmuhukum, yakni dogmatic hukum, teori hukum dan filsafat hukum. (Sekretariat Jenderal DPR RI, 2008). Pendekatan penelitian yang digunakan dalam penelitian ini adalah pendekatan undang-undang. (Statute Approach) yaitu pendekatan undang- undang yang dilakukan dengan menelaah semua undang- undang dan regulasi yang bersangkut paut dengan isu hukum yang sedang ditangani. (Marzuki, 2009). Penelitian normatif ini menggunakan bahan sekunder, yaitu bahan yang diperoleh dari studi kepustakaan. Bahan hukum primer yaitu bahan-bahan hukum yang mempunyai kekuatan mengikat, yang terdiri dari Peraturan Perundan-Undangan. Bahan SekunderYaitu bahan hukum yang memberikan penjelasan badan hukum primer, meliputi: Buku-buku Literatur, Hasil-hasil penelitian, seminar, sosialisasi atau penemuan ilmiah, Ketentuan-ketentuan lain yang relevan dengan objek kajian penelitian. Bahan Tersier yaitu bahan Hukum Kamus yang digunakan untuk melengkapi 
bahan hukum primer dan bahan hukum sekunder, meliputi: Koran, majalah, jurnal ilmiah, Internet, kamus hukum dan referensi-referensi lainnya yang relevan.

Dalam penulisan ini penulis mengumpulkan bahan melalui Penelitian Kepustakaan (library research) dilakukan untuk mendapatkan teori-teori hukum, doktrin-doktrin asas-asas hukum dan pemikiran hukum konseptual, yang berkaitan dengan objek kajian penelitian ini yang dapat berupa Peraturan Perundang-Undangan, penelitian terdahulu, literatur hukum dan karya tulis di bidang hukum lainnya.

Analisis bahan hukum yang digunakan penulis adalah analisis bahan hukum kualitatif yaitu menguraikan bahan secara bermutu dalam bentuk kalimat yang teratur, namun logis dan tidak tumpang tindih dan efektif sehingga memudahkan intepretasi bahan dan pemahaman hasil analisis yang kemudian diatarik suatu kesimpulan secara deduktif yaitu cara berpikir dengan menarik kesimpulan bahan yang bersifat umum ke yang bersifat khusus. (Nasution, 2008).

\section{Hasil Pembahasan}

Perjanjian Pembiayaan Konsumen sebagai bentuk perjanjian khusus atau biasa disebut dengan perjanjian tak bernama, karena tidak disebutkan secara tegas dalam buku III KUH Perdata yang mengatur tentang perikatan. Dalam KUH Perdata tidak dikenal nama "Perjanjian Pembiayaan maupun Perjanjian Kredit, namun dengan adanya asas kebebasan berkontrak yang diatur dalam Pasal 1338 KUH Perdata, dimana setiap orang bebas dan terbuka untuk membuat hubungan hukum perikatan apapun sepanjang tidak bertentangan dengan syarat sahnya perjanjian sebagaimana diatur dalam pasal 1320 KUH Perdata. (Witanto, 2015).

Perjanjian Pembiayaan Konsumen secara substansial merupakan bentuk perjanjian gabungan antara perjanjian jual beli, utang piutang (kredit) dan perjanjian jaminan, sehingga setidaknya dalam perjanjian Pembiayaan Konsumen akan terlibat 3 (tiga) pihak, antara lain: (Witanto, 2015).

1. Pihak Konsumen yang memiliki kepentingan untuk membeli suatu barang namun ia tidak memiliki dana yang cukup;

2. Pihak lembaga pembiayaan (finance) yang memiliki modal dan memberikan pembiayaan kepada konsumen untuk membeli barang yang dibutuhkan;

3. penjual atau pemilik barang yaitu pihak yang menjualkan barangnya kepada konsumen dengan pembayaran tertentu.

Berdasarkan sifat perikatan yang lahir dari hubungan hukum pembiayaan, maka dalam perjanjian pembiayaan setidaknya mengandung beberapa hubungan hukum, antara lain: (Witanto, 2015). 
1. Perjanjian jual beli, dimana konsumen (debitor) berangkat dari maksud untuk membeli sebuah barang;

2. Perjanjian utang piutang, dimana pihak perusahaan pembiayaan mengeluarkan sejumlah uang untuk membiayai kebutuhan konsumen dalam membeli barang yang dibutuhkan sebagai utang yang harus di bayar oleh pihak konsumen dengan cara pembayaran secara mencicil;

3. Perjanjian Penjaminan, dimana untuk menjamin utang yang timbul dari pemberian pembiayaan tersebut, maka barang yang dibeli oleh konsumen diserahkan kembali hak miliknya sebagai jaminan secara fidusia.

Perjanjian Pembiayaan memiliki hubungan dengan perjanjian jual-beli, perjanjian utangpiutang dan perjanjian penjaminan, dimana untuk menjamin utang yang timbul dari pemberian pembiayaan tersebut, maka barang yang dibeli oleh konsumen yang dibiayai oleh Lembaga Pembiayaan diserahkan kembali hak miliknya sebagai jaminan secara fidusia kepada Lembaga Pembiayaan. (Witanto, 2015).

Fidusia diatur dalam Undang-Undang Nomor 42 Tahun 1999 tentang Jaminan Fiduisa. Ketentuan dalam Pasal 1 angka 1 Undang-Undang Nomor 42 Tahun 1999 tentang Jaminan Fidusia menyatakan: (Usman, 2009).

Fidusia adalah pengalihan hak kepemilikan suatu benda atas dasar kepercayaan dengan

ketentuan bahwa benda yang hak kepemilikannya dialihkan tersebut tetap dalam penguasaan pemilik benda.

Berdasarkan pengertian fidusia diatas secara tersirat mengatakan bahwa seseorang baru dapat menjaminkan benda apabila seseorang itu adalah pemilik benda atau sudah menjadi pemilik.

Perjanjian Pembiayaan Konsumen secara substansial merupakan bentuk perjanjian gabungan antara perjanjian jual beli, utang piutang (kredit) dan perjanjian jaminan, sehingga setidaknya dalam perjanjian Pembiayaan Konsumen akan terlibat 3 (tiga) pihak, antara lain: (Witanto, 2015).

1. Pihak Konsumen yang memiliki kepentingan untuk membeli suatu barang namun ia tidak memiliki dana yang cukup;

2. Pihak lembaga pembiayaan (finance) yang memiliki modal dan memberikan pembiayaan kepada konsumen untuk membeli barang yang dibutuhkan;

3. penjual atau pemilik barang yaitu pihak yang menjualkan barangnya kepada konsumen dengan pembayaran tertentu. 
Hubungan hukum yang timbul dari para pihak tersebut dapat digambarkan dalam sebuah skema sebagai berikut:

Dari hubungan hukum sebagaimana ditunjukkan diatas dapat dijelaskan sebagai berikut: antara konsumen dengan penjual terjadi hubungan hukum jual beli dimana konsumen membayar uang muka atas barang, dan pihak konsumen berhak untuk menerima penyerahan barang, lalu konsumen mengajukan permohonan pembiayaan ke lembaga pembiayaan, dan lembaga pembiayaan menyetujui permohonan pembiayaan, lalu lembaga pembiayaan membayar sisa pembayaran atas nama konsumen kepada penjual, setelah penjual menyerahkan tanda terima barang kepada lembaga pembiayaan, maka tidak ada lagi hubungan antara penjual dan konsumen, Uang pembelian dari pembiayaan untuk kepentingan pembelian barang bagi konsumen kemudian melahirkan hubungan utang piutang antara pihak konsumen dengan lembaga pembiayaan senilai uang pembelian barang berikut bunga yang telah ditentukan dan segala ongkos-ongkos lainnya dengan sistem pembayaran secara angsuran dengan jangka waktu yang disepakati antara pihak pembiayaan dan pihak konsumen, atas hubungan utang piutang yang timbul, kemudian pihak konsumen menyerahkan hak milik barang yang dibeli dengan pembiayaan tersebut sebagai jaminan atas utangnya kepada pihak pembiayaan dengan jaminan secara Fidusia. (Witanto, 2015).

Dalam perjanjian pembiayaan pihak konsumen mendapatkan dana dari perusahaan pembiayaan, maka si konsumen akan terhutang sebesar nilai pembiayaan ditambah dengan bunga yang diperjanjikan dan ongkos-ongkos lainnya. Untuk menjamin perikatan utang piutang tersebut antara konsumen dengan lembaga pembiayaan lalu diikatlah perjanjian Jaminan Fidusia antara pihak konsumen dengan pihak lembaga pembiayaan. Perlu kita ingat bahwa agar hubungan hukum jaminan itu sah, maka pihak yang menjaminkan harus orang yang memiliki barang tersebut, sehingga dengan logika seperti itu, maka kepemilikan barang dianggap telah beralih kepada pihak konsumen sejak barang itu diserahkan kepadanya dari pihak penyedia barang karena tidak mungkin si konsumen dikatakan telah menjaminkan barang tersebut jika ia belum menjadi pemiliknya, selain itu pihak perusahaan pembiayaan menanggung pembayaran untuk kepentingan konsumen sehingga jual beli tersebut tetap harus dipandang antara pihak penyedia barang dengan pihak konsumen meskipun dana yang digunakan untuk pembayaran berasal dari pihak perusahaan pembiayaan. (Witanto, 2015).

\section{Simpulan}

Tindakan menjaminkan barang objek fidusia yang pembayarannya oleh pemegang fidusia kepada penjual adalah sah. Karena pembeli (pemberi fidusia) sudah berstatus sebagai pemilik barang tersebut. Oleh karenanya tindakan menjaminkan melalui penyerahan hak milik saja sesuai 
dengan apa yang diatur dalam Undang-Undang Jaminan Fidusia. Perlu kita ingat bahwa agar hubungan hukum jaminan itu sah, maka pihak yang menjaminkan harus orang yang memiliki barang tersebut, sehingga dengan logika seperti itu, tidak mungkin si konsumen dikatakan telah menjaminkan barang tersebut jika ia belum menjadi pemilik.

Pemberi Fidusia sudah berstatus sebagai pemilik barang walaupun harganya belum dibayar kepada penjual, karena telah terjadi jual beli dan penyerahan (levering) antara pembeli (pemberi fidusia) dan penjual. Dengan adanya Perjanjian Fidusia maka hak milik atas barang itu ia (pembeli/pemberi fidusia) serahkan kepada Lembaga Pembiayaan (penerima fidusia) sehingga kedudukan pemberi fidusia hanyalah pemakai. Uang pinjaman yang diperoleh dari Lembaga Pembiayaan atas dasar kuasa dari pembeli dibayarkan kepada penjual, sehingga tidak ada lagi hubungan hukum antara pembeli dan penjual (dealer). Yang ada hanyalah pinjam meminjam uang antara pemberi fidusia (pembeli) dengan Lembaga Pembiayaan.

\section{DAFTAR PUSTAKA}

\section{Buku}

Gozali, D. S. (2012). Hukum Perbankan. Indonesia : Sinar Grafika.

HS, S. (2008). Perkembangan Hukum Jaminan Di Indonesia. Jakarta: Rajawali Pers.

Marzuki, P. M. (2009) Penelitian Hukum. Jakarta: Kencana Prenada Media Group.

Nasution, B. J. (2008) Metode Penelitian Hukum. Bandung: Mandar Maju.

Penyelenggaraan Usaha Perusahaan Pembiayaan (2014). Indonesia.

RI, S. J. D. (2008). Modul Perancangan Undang-Undang. Jakarta: Sekretariat Jenderal DPR RI.

Subekti, R. (1980). Kitab Undang-Undang Hukum Perdata.

Sunaryo (2014). Hukum Lembaga Pembiayaan. Jakarta: Sinar Grafika.

Usman, R. (2009). Hukum Jaminan Kebendaan. Jakarta: Sinar Grafika.

Witanto, D. Y. (2015). Hukum Jaminan Fidusia Dalam Perjanjian Pembiayaan Konsumen. Bandung: CV. Mandar Maju.

\section{Artikel Jurnal}

Aemadepa. (2012). Pendaftaran Jaminan Fidusia, Masalah Dan Dilema Pelaksanaannya, vol (5).,No. (1), p. 725.

(https://library.pancabudi.ac.id/jurnal_files/38de8fa1a32b0d8231452571870213670592d21

a_3._Aermadeva.pdf)

Andini, I. Y. (2018). Kedudukan Fidusia Sebagai Jaminan Akad Pembiayaan Murabahah Pada 
Bank Syariah: Studi Kasus Pada BPRS Bhakti Sumekar Sumenep', 29 No. 2, p. 2.

(https://r.search.yahoo.com/_ylt=AwrxgzN.zN9dbSsAugj3RQx.;_ylu=X3oDMTByYmpm ZjA4BGNvbG8Dc2czBHBvcwMzBHZ0aWQDBHNIYwNzcg--

$/ \mathrm{RV}=2 / \mathrm{RE}=1574976767 / \mathrm{RO}=10 / \mathrm{RU}=\mathrm{https} \% 3 \mathrm{a} \% 2 \mathrm{f} \% 2$ fjurnal.umj.ac.id\%2findex.php\%2f MaA16\%2farticle \%2fdownload\%2f2857\%2fpdf/RK=2/RS=_H4Kf3xdMO3OATIqZjgNH .iVOWo-)

Purwanto. (2012). Beberapa Permasalahan Perjanjian Pembiayaan Konsumen Dengan Jaminan Fidusia', 1 No. 2, p. 203.

(https://rechtsvinding.bphn.go.id/artikel/ARTIKEL\%203\%20Vol\%201\%20No\%202.pdf)

\section{Undang-undang dan Peraturan}

Keputusan Presiden Republik Indonesia Nomor 61 Tahun 1988 Tentang Lembaga Pembiayaan (1998). Indonesia.

Peraturan Otoritas Jasa Keuangan Nomor 29/POJK.05/2014 tentang Penyelenggaraan Usaha Perusahaan Pembiayaan (2014). Indonesia.

Peraturan Presiden Republik Indonesia Nomor 9 Tahun 2009 Tentang Lembaga Pembiayaan (2009). Indonesia.

Subekti, R. (1980) Kitab Undang-Undang Hukum Perdata 